\title{
Purinergic Signaling in Gut Inflammation: The Role of Connexins and Pannexins
}

\author{
Erica F. Diezmos ${ }^{1}$, Paul P. Bertrand ${ }^{1,2}$ and Lu Liu ${ }^{1 *}$ \\ ${ }^{1}$ School of Medical Sciences, University of New South Wales, Sydney, NSW, Australia, ${ }^{2}$ School of Medical Sciences, RMIT \\ University, Bundoora, VIC, Australia
}

Purinergic receptors play an important role in inflammation, and can be activated by ATP released via pannexin channels and/or connexin hemichannels. The purinergic P2X7 receptor (P2X7R) is of interest since it is involved in apoptosis when activated. Most studies focus on the influence of pannexin-1 (Panx1) and connexin 43 (Cx43) on ATP release and how it affects $\mathrm{P} 2 \mathrm{X} 7 \mathrm{R}$ function during inflammation. Inflammatory bowel disease (IBD) is characterized by uncontrolled inflammation within the gastrointestinal system. At present, the pathophysiology of this disease remains largely unknown but it may involve the interplay between P2X7R, Panx1, and Cx43. There are two main types of IBD, ulcerative colitis and Crohn's disease, that are classified by their location and frequency of inflammation. Current research suggests that alterations to normal functioning of innate and adaptive immunity may be a factor in disease progression. The involvement of purinergic receptors, connexins, and pannexins in IBD is a relatively novel notion in the context of gastrointestinal inflammation, and has been explored by various research groups. Thus, the present review focuses on the current research involving connexins, pannexins, and purinergic receptors within the gut and enteric nervous system, and will examine their involvement in inflammation and the pathophysiology of IBD.

Keywords: purinergic receptors, connexins, pannexins, inflammatory bowel disease, gastrointestinal inflammation

\section{INTRODUCTION}

Extracellular ATP can act on purinergic receptors in the gastrointestinal (GI) system to mediate a variety of actions depending on the receptor type and localization (Surprenant and North, 2009; Burnstock, 2014; Ochoa-Cortes et al., 2014). ATP is involved in excitatory neurotransmission within the enteric nervous system (ENS) via P2X receptors (P2XR) and P2Y receptors (P2YR) (Burnstock and Williams, 2000; Monro et al., 2004; Gallego et al., 2006, 2008; Ren and Bertrand, 2008). ATP acts as both an autocrine and paracrine molecule, altering ion transport, cell-cell communication, and inflammation (Burnstock and Williams, 2000; Boisse et al., 2009; Corriden and Insel, 2010; Junger, 2011; Roberts et al., 2012). Among the various types of purinergic receptors, the P2X7R is of particular interest as its activation promotes inflammation

Diezmos EF, Bertrand PP and Liu L (2016) Purinergic Signaling in Gut Inflammation: The Role of Connexins and Pannexins.

Front. Neurosci. 10:311. doi: 10.3389/fnins.2016.00311

Abbreviations: CD, Crohn's disease; COPD, chronic obstructive pulmonary disease; Cx, connexin; DSS, dextran sulfate sodium; ENS, enteric nervous system; GI, gastrointestinal; IBD, inflammatory bowel disease; Panx1, pannexin-1; Panx2, pannexin-2; Panx3, pannexin-3; P2XR, P2X receptors; P2YR, P2Y receptors; P2X7R, P2X7 receptors; TNBS, trinitrobenzene sulfonic acid; UC, ulcerative colitis. 
by increasing inflammatory cytokine release from immune cells in the presence of stimuli such as lipopolysaccharide (Bianco et al., 2005; Pelegrin and Surprenant, 2006; Surprenant and North, 2009; Idzko et al., 2014). The involvement of purinergic receptors in the pathophysiology of inflammatory diseases is a recurring theme and has been studied in the context of inflammatory bowel disease (IBD) in conjunction with exploring the mechanisms of ATP release. More recently, studies have focused on the involvement of two families of protein channels that have been shown to mediate ATP release extracellularly: the gap junction family of connexin channels, and the more novel pannexin channels.

Connexins are known for forming gap junctions between two adjacent cells, but can also form unopposed hemichannels that allow small hydrophilic molecules such as nucleotides and ions, to pass across the cellular bilayer (Vinken et al., 2010). Connexin (Cx) subtypes are classified according to their molecular weight and certain types of connexin hemichannels such as $\mathrm{Cx} 43$ may be involved in extracellular release of ATP (Fortes et al., 2004; Kang et al., 2008; Wang et al., 2013a; Csoka et al., 2015; Brown et al., 2016). Pannexin channels are structurally similar to connexin hemichannels, with both being made up of six subunits that exist either in homomeric (consisted of the same subunits) or heteromeric (made up of different subunits) states (D'Hondt et al., 2009). However, connexins and pannexins do not share sequence homology and thus are genetically unrelated (Baranova et al., 2004). There are three types of pannexins that differ at the $\mathrm{N}$ and $\mathrm{C}$ termini of their subunits: pannexin-1 (Panx1), pannexin-2 (Panx2), and pannexin-3 (Panx3) (Baranova et al., 2004). Panx1 is ubiquitous and the most well-studied in the literature. Similar to connexins, many studies have provided evidence to support a role for pannexins as ATP release channels in various systems (Schenk et al., 2008; Ransford et al., 2009; Woehrle et al., 2010a; Junger, 2011; Xia et al., 2012; Orellana et al., 2013; Beckel et al., 2014). Both pannexin channels and connexin hemichannels are thought to act as "ATP release channels" or conduits for ATP transport from the cell cytosol to the extracellular fluid (Locovei et al., 2006a; Lohman and Isakson, 2014). Panx1 and Cx43 channels have been shown to open under a variety of conditions, for example, after activation of purinergic receptors, mechanical stress or altered levels of intracellular $\mathrm{Ca}^{2+}$ (Bao et al., 2004; Locovei et al., 2006b; Burra and Jiang, 2009; De Vuyst et al., 2009). Channel opening is most likely regulated by elevated levels of extracellular ATP (Qiu and Dahl, 2009; Lohman and Isakson, 2014).

The present review will focus on current research involving purinergic receptors, connexins, and pannexins within the gut and the ENS, with a focus on their role during inflammation. The review will also explore their roles in models of inflammation in other organ systems to provide an insight on possible mechanisms of etiology in IBD.

\section{PURINERGIC RECEPTORS AND THEIR INVOLVEMENT IN INFLAMMATION}

\section{Subtypes of Purinergic Receptors}

Purinergic P2 receptors are classified into two main categories: the P2XR and the P2YR. P2XR are ATP-gated trimeric ion channels, and P2YR exist as G-protein coupled receptors (Ralevic and Burnstock, 1998; von Kugelgen and Harden, 2011). Both receptors are further classified into their subtypes. P2XR are numbered from 1 to 7 (P2X1-P2X7) (Ralevic and Burnstock, 1998). P2YR subtypes are divided into P2Y1-like receptors (P2Y1, P2Y2, P2Y4, P2Y6, P2Y11) and P2Y12-like receptors (P2Y12, P2Y13, P2Y14) where only P2Y2 and P2Y11 have ATP as their main endogenous ligand (von Kugelgen and Harden, 2011). $\mathrm{P} 2 \mathrm{X} 7 \mathrm{R}$ are of considerable interest in inflammation since this is the only subtype that is resistant to desensitization (North, 2002). Thus, it can be activated for a prolonged period of time and can function in positive feedback signaling that is observed in events such as apoptosis (North, 2002; Locovei et al., 2007; Kurashima et al., 2012; Idzko et al., 2014; Kuhny et al., 2014).

\section{Expression of P2X Receptors in the Intestine}

All of the P2XR have been detected in the mammalian gut, however, not all receptor subtypes have established roles. P2X1R are found at sympathetically innervated smooth muscles and function as neurotransmitter receptors where they exist as homomeric ATP gated ion channels (Ralevic and Burnstock, 1998; Surprenant and North, 2009). P2X2R are present in the myenteric ganglia of the ENS and are most likely expressed in intrinsic primary afferent neurons, inhibitory motor neurons, non-cholinergic secretomotor neurons, and on vagal afferent nerve endings in the stomach (Castelucci et al., 2002). P2X3R are present on cholinergic secretomotor neurons, ascending interneurons, and on both excitatory and inhibitory motor neurons (Poole et al., 2002). P2X4R are expressed in the rat pyloric sphincter, rat intestinal crypts, parotid glands, and salivary glands (Tanaka et al., 1996; Tenneti et al., 1998). P2X5R are found on canine longitudinal muscle, enteric ganglia on mouse intestine, and on interstitial cells of Cajal in guinea pig intestine (Ruan and Burnstock, 2005). P2X6R mRNA was only found in rat bile duct (Doctor et al., 2005). In contrast, the P2X7R is expressed throughout the intestine in a variety of tissue types including intestinal epithelial cells, mast cells, macrophages, and lymphocytes (Martin et al., 1998; Ralevic and Burnstock, 1998; Pelegrin et al., 2008; Cesaro et al., 2010; Idzko et al., 2014; Kuhny et al., 2014; Shoji et al., 2014). The P2X7R is also expressed in the enteric ganglia of rodents where it was found localized to intrinsic primary afferent neurons, inhibitory motor neurons and glial cells (Vanderwinden et al., 2003; Cesaro et al., 2010; de Campos et al., 2012; Gulbransen et al., 2012; da Silva et al., 2015). Table 1 summarizes P2XR localization in the intestine.

\section{P2X7 Receptors in Inflammatory Bowel Disease}

Recent studies have suggested roles for P2X7R in areas such as cell proliferation, tumor growth, and neural cell function (Vanderwinden et al., 2003; Adinolfi et al., 2012; Rigato et al., 2012; Bartlett et al., 2014; Hofman et al., 2015). However, the P2X7R, when activated by ATP, is best established as an important player in inflammation and apoptosis as it has been shown to enable pro-inflammatory cytokine release from immune cells (Bianco et al., 2005; Pelegrin and Surprenant, 2006; Idzko et al., 2014). In addition to its role in the inflammatory 
TABLE 1 | Localization of P2X receptors in the intestine.

\begin{tabular}{|c|c|}
\hline Receptor & Localization in the gastrointestinal system \\
\hline P2X1R & Sympathetically innervated smooth muscles \\
\hline P2X2R & $\begin{array}{l}\text { Intrinsic primary afferent neurons, inhibitory motor neurons, } \\
\text { non-cholinergic secretor motor neurons, and on vagal afferent } \\
\text { nerve endings in the stomach }\end{array}$ \\
\hline P2X3R & $\begin{array}{l}\text { Cholinergic secretomotor neurons, ascending interneurons, } \\
\text { excitatory and inhibitory motor neurons }\end{array}$ \\
\hline P2X4R & $\begin{array}{l}\text { Rat pyloric sphincter, rat intestinal crypts, parotid glands, and } \\
\text { salivary glands }\end{array}$ \\
\hline P2X5R & $\begin{array}{l}\text { Canine longitudinal muscle, mouse enteric ganglia, and } \\
\text { guinea pig interstitial cells of Cajal }\end{array}$ \\
\hline P2X6R & Bile duct \\
\hline \multirow[t]{2}{*}{ P2X7R } & Epithelial cells, mast cells, macrophages, and lymphocytes \\
\hline & $\begin{array}{l}\text { Enteric ganglia expression: intrinsic primary afferent neurons, } \\
\text { inhibitory motor neurons, and glial cells }\end{array}$ \\
\hline
\end{tabular}

response, the P2X7R has been explored in the context of IBD, which has the characteristics of inflammation and dysmotility (Locovei et al., 2006b, 2007; Pelegrin and Surprenant, 2009; Gulbransen et al., 2012; Roberts et al., 2012; Antonioli et al., 2014). In one clinical study, patients with Crohn's Disease (CD) were observed to have a higher expression of P2X7R and higher apoptotic rates in the mucosa layer of the colon (Neves et al., 2014). Most studies of P2X7R in animal models of colitis that have attempted to counteract the alterations in P2X7R expression have concluded that there is a significant role for P2X7R. In one study of a rat colitis model induced by trinitrobenzene sulfonic acid (TNBS), blockade of the P2X7R resulted in the reduction of T-cell and macrophage infiltration in the lamina propria and a decrease in the overall severity of inflammation (Marques et al., 2014). In another preclinical study, P2X7R $\mathrm{R}^{-/-}$ mice subjected to TBNS or dextran sulfate sodium (DSS) failed to develop inflammation or other symptoms associated with colitis, implying an important role for P2X7R in the inflammatory process (Neves et al., 2014). A recent study using a TNBS rat model of experimental ulcerative colitis (UC) showed that there was an $11 \%$ decrease in the density of P2X7R immunoreactive neuronal cell bodies (da Silva et al., 2015). Much of the recent research that has explored the P2X7R in IBD has also studied the role of connexins and/or pannexins in ATP release. This will be discussed later in the present review.

\section{Other Purinergic Receptors in Inflammatory Bowel Disease}

Although the P2X7R appears to play a key role in IBD, other purinergic receptor subtypes may also contribute to or be affected by IBD pathophysiology. Guzman et al. observed an upregulation of mRNA for P2X1R, P2X4R, P2X7R, P2Y2R, and $\mathrm{P} 2 \mathrm{Y} 6$ receptors in a rat model of TNBS-induced colitis (Guzman et al., 2006). A later bioinformatics study found that genetic dysregulation in IBD was observed in $59 \%$ of purine genes such as P2Y5R, P2Y6R, P2Y13R, P2Y14R, and P2X5R (Rybaczyk et al., 2009). The P2X3R was observed to have changes in expression of mRNA in both patients with $\mathrm{CD}$ or with UC, where immunoreactivity on the enteric ganglia of IBD was increased (Yiangou et al., 2001). A more recent study observed a downregulation in immunoreactivity of $\mathrm{P} 2 \mathrm{X} 3 \mathrm{R}$ in enterochromaffin cells of specimens from UC patients which may influence the autocrine regulatory role of ATP that is involved in the release of 5-HT from these cells (Linan-Rico et al., 2013; Patel, 2014). In another preclinical study using TNBS-induced colitis in mice, protein expression of P2X1R was upregulated in the submucosa of colitis tissue and degradation of ATP by nucleotidases was increased during colitis (Lomax et al., 2007). The role of nucleotidases will be discussed further below.

\section{Role of Ectonucleotidases in Inflammatory Bowel Disease}

Ectonucleotidases are responsible for the degradation of ATP once released and are found to be significantly altered in IBD (Antonioli et al., 2013). In a DSS mouse model of colitis, CD39 deletion was shown to exacerbate colitis (Friedman et al., 2009). In the same study, it was shown in humans that single nucleotide polymorphisms with low CD39 expression were associated with CD (Friedman et al., 2009). CD patients have also been observed to have lower CD39 expression in Th17 cells (Longhi et al., 2014). In addition, $\mathrm{UC}$ and $\mathrm{CD}$ patients undergoing remission after treatment from anti-tumor necrosis factor therapy were found to have elevated CD39 expression on T-regulatory cells (Gibson et al., 2015). CD73 has been studied in the context of a CD73-/mouse DSS colitis model, where exacerbated inflammation of DSS colitis was observed in the knockouts (Bynoe et al., 2012). The changes observed in these ectonucleotidases may influence purinergic receptor activation; for instance, it has been demonstrated that a knockout of CD39 reduced P2X7R responses in mast cells (Kuhny et al., 2014). Increases in ATP levels associated with a downregulation of ectonucleotidases may exacerbate P2XR activation and inflammation in other cells.

\section{CONNEXINS AND THEIR ROLES IN ATP RELEASE AND INFLAMMATION}

Connexin gap junctions and hemichannels are expressed throughout different types of mammalian tissues. Within the intestine, the range of connexins includes the following: $\mathrm{Cx} 26$, Cx32, Cx36, Cx37, Cx43, and Cx45 (Wang and Daniel, 2001; Kanczuga-Koda et al., 2004; Morita et al., 2004; Clair et al., 2008; Ezumi et al., 2008; Frinchi et al., 2013).

\section{Cx43 Hemichannels}

The most studied subtype of connexins in the context of intestinal inflammation and motility is Cx43. The Cx43 hemichannel has been shown to open to allow for the release of ATP, which has been demonstrated in many cell types such as $\mathrm{Cx} 43$ transfected C6 cells and polymorphonuclear leukocytes (Eltzschig et al., 2006; Kang et al., 2008). Cx43 is proposed to be involved in microglial survival where ATP release is modulated by $\mathrm{Cx} 43$ hemichannel opening (Ma et al., 2014). In macrophages, it has been suggested that $\mathrm{Cx} 43$ is colocalized with P2X7R and that together they mediate intercellular communication via gap 
junction formation that is influenced by extracellular ATP (Fortes et al., 2004). In one study which further emphasizes its role in inflammation, $\mathrm{Cx} 43$ was suggested to be the conduit for extracellular release of prostaglandin (PG) $\mathrm{E}_{2}$ (Cherian et al., 2005). Interestingly, in another study PGE-ethanolamides and PGF-ethanolamides were shown to be protective against tissue damages in a human explant colitis model induced by TNF $\alpha$ and IL-1 $\beta$ (Nicotra et al., 2013). Cx43 has been linked to inflammation of the intestine and diarrhea due to bacterial infection, where an increase of $\mathrm{Cx} 43$ was linked to increased occurrence of bacterial infection in colonocytes (Guttman et al., 2010; Vinken et al., 2010). Cx43 has been implicated in facilitating internalization of bacteria and overall mucosal integrity (Velasquez Almonacid et al., 2009; Bou Saab et al., 2014). Studies that have looked at $\mathrm{Cx} 43$ in the context of gut motility have focused on $\mathrm{Cx} 43$ expression on smooth muscle and enteric ganglia and its role in calcium wave propagation. In one study using transgenic mice with conditional deletion of $\mathrm{Cx} 43$ in intestinal smooth muscle, there was a $29 \%$ decrease in GI transit time (Doring et al., 2007). Intracellular calcium has been suggested to regulate $\mathrm{Cx} 43$, where a lack of $\mathrm{Cx} 43$ delayed overall colonic transit time (Lurtz and Louis, 2007; McClain et al., 2014). Thus, the abnormality of connexins, particularly $\mathrm{Cx} 43$, may be involved in both intestinal dysmotility and inflammation that is associated with IBD and other intestinal conditions.

\section{Cx32, Cx36, Cx37, and Cx45 Hemichannels}

$\mathrm{Cx} 32$ hemichannels have also been suggested to release ATP in response to increases in intracellular calcium ions in transfected C6 glioma cells (De Vuyst et al., 2006). Cx36 is expressed in mouse myenteric ganglia, and $\mathrm{Cx} 36$ in rat neuron cultures was suggested to release ATP during depolarization of neurons (Schock et al., 2008; Frinchi et al., 2013). In a study by Koutsoumpas et al. the presence of autoantibodies for Cx37 was determined in a cohort of CD patients, suggesting CD patients developed an autoimmunity to resident $\mathrm{Cx} 37$ and thus may be involved in IBD pathogenesis (Koutsoumpas et al., 2011). In mongrel dogs, varying levels of immunoreactivity for $\mathrm{Cx} 45$ were observed along the GI tract, with some $\mathrm{Cx} 45$ protein present on myenteric and submucosal gangliaand sparse immunoreactivity on the circular muscle of the esophageal sphincter and ileum (Wang and Daniel, 2001).

\section{PANNEXIN CHANNELS AND THEIR INVOLVEMENT IN INFLAMMATION}

Pannexin channels are relatively newly identified ATP release channels. They were discovered based on their sequence similarity to innexins, the gap junction proteins of invertebrates (Baranova et al., 2004). Among the three types of pannexin in mammals, Panx1 channels are ubiquitous in mammalian tissues and have an extensive list of functions that have been ascribed to them. Panx2 proteins are localized to the central nervous system and more recently have been found in enteric neurons (Baranova et al., 2004; Lai et al., 2009; Swayne et al., 2010; Li et al., 2011; Diezmos et al., 2015). Panx3 is expressed in skin and cartilage, and has been suggested to act as an ATP release channels in these tissues (Bruzzone et al., 2003; Ishikawa et al., 2011). Pannexins do not form gap junctions and exist solely as cell membrane channels (D'Hondt et al., 2009). Their role as ATP release channels was reported soon after their discovery. Under stimuli such as mechanical stress, the channel can open to release intracellular ATP into the extracellular space which in turn can act on P2XR or P2YR in the vicinity (Locovei et al., 2006b; Xia et al., 2012; Beckel et al., 2014).

Panxl has been shown to be involved in ATP release in different models of inflammation. Pharmacological blockade of Panx1 was shown to decrease IL- $1 \beta$ release and caspase1 production in J774 macrophages (Pelegrin and Surprenant, 2006). Other studies have investigated T-cells in relation to antigen presentation, where Panx1, P2X1R, and P2X4R were found to mediate calcium entry into the T-cells and IL-2 production (Woehrle et al., 2010a). These events occur as a result of the translocation of Panx1, P2X1R, and P2X4R toward the "immune synapse," a complex formed during $\mathrm{T}$ cell activation (Woehrle et al., 2010a). Another study found that T-cell receptor activation leads to calcium ion influx, which causes the extracellular release of ATP via Panx1 channels (Schenk et al., 2008). T-cells were also suggested to participate in cell death that involves Panx 1 channels acting downstream of activated P2X7R (Shoji et al., 2014). In the Jurkat T-cell line, Panxl was found to be crucial in regulating fragmentation of apoptotic cells (Poon et al., 2014). In addition, Panx1 was shown to mediate release of nucleotides from apoptotic cells which signals for the recruitment of phagocytes (Chekeni et al., 2010). Panxl expressed in neutrophils is suggested to function in conjunction with $\mathrm{P} 2 \mathrm{Y} 2 \mathrm{R}$ in an autocrine fashion to mediate chemotaxis (Bao et al., 2013).

Expression of Panx1 and purinergic receptors in a range of immune cells has thus led to research into their roles in various inflammatory diseases. P2X7R and Panx1 are shown to participate in neutrophil activity and recruitment, as well as IL-1 $\beta$ release in a study focusing on chronic obstructive pulmonary disease (COPD) (Riteau et al., 2010). Blockade of Panx1 function attenuated the elevation of ATP levels normally observed in COPD (Baxter et al., 2014). A recent study in mice has suggested that $\mathrm{P} 2 \mathrm{X} 7 \mathrm{R}$ is involved in brain ischemia alongside Panx1 and together are thought to be involved in a neuroprotective mechanism of ischemia pre- and post-conditioning, and in improved memory and motor functions in mice with ischemiareperfusion-induced cerebral injury (Mahi et al., 2015). In an autoimmune encephalomyelitis mouse model for multiple sclerosis, P2X7R is upregulated during the chronic phase of the disease (Lutz et al., 2013). Blockade of functioning Panx1 channels reduced clinical signs of encephalomyelitis (Lutz et al., 2013). Panx1-/- and Panx $2^{-/-}$double knockout mice were more resistant to ischemic stroke, which was not observed in single Panx1 $1^{-/-}$or Panx $2^{-/-}$knockouts (Bargiotas et al., 2011). A further study demonstrated that exploration, sensorimotor functions, anxiety, and behavioral symmetry in the double knockout mice were improved (Bargiotas et al., 2012).

The aforementioned disease models thus have the following in common with IBD: infiltration of neutrophils and other 
immune cells, changes in cytokine release, and alterations in either pannexin and/or purinergic receptors. Similar to connexins, pannexins are expressed in the ENS within enteric ganglia and other cells involved in the immune response, making pannexins potential players alongside connexins in ATP associated dysmotility and inflammation (Gulbransen et al., 2012; Diezmos et al., 2013, 2015). Panx1 expression was found to be reduced in the ENS of CD patients but not in UC patients (Gulbransen et al., 2012). In contrast, immunohistochemistry results have shown that Panx1 immunoreactivity on human colonic tissues was almost abolished in myenteric ganglia of specimens from UC patients but not in those from CD patients (Diezmos et al., 2013). Interestingly, the decrease in Panx1 protein expression in CD as observed by Gulbransen and colleagues was also demonstrated by Diezmos et al. using Western blot analysis (Gulbransen et al., 2012; Diezmos et al., 2013). Panx2 has also been examined in human colonic tissues where up-regulation of Panx 2 mRNA was found in the muscularis layer of UC specimens, though this was not reflected at the protein level or immunoreactivity (Diezmos et al., 2015). The limited and conflicting results presented here warrant further studies in this area; specifically to confirm the true expression profile of Panx1 in normal intestine and IBD tissues, to determine the extent in which pannexins and connexins contribute to extracellular ATP signaling in IBD pathophysiology, and to map the process of events leading to inflammation.

\section{INTERACTIONS BETWEEN CONNEXINS, PANNEXINS, AND PURINERGIC RECEPTORS IN INFLAMMATORY BOWEL DISEASE}

Currently, there are a handful of studies that have examined the interactions between connexins, pannexin, and purinergic receptors. Of these studies, only a few have looked at these proteins in the context of IBD. The study conducted by Gulbransen et al. was the first to look at Panx1 and P2X7R in IBD, examining expression and function in a mouse model of colitis and in human samples from UC and CD patients (Gulbransen et al., 2012). In a mouse model of colitis it was shown that inhibition of P2X7R, Panx1, the adaptor protein apoptosisassociated speck-like protein containing CARD (ASC) or caspase activity attenuated the inflammation process that caused enteric cell death (Gulbransen et al., 2012).

The localization of connexins, pannexins, and purinergic receptors within the gut regions and tissues may provide insight into their specific roles in inflammation. Panx1 expression is ubiquitous and is found on glandular epithelium, nonlymphoid leukocytes, blood vessel endothelium, erythrocytes, varicosities within ganglia, and muscle tissue (Diezmos et al., 2013). Panx 2 is localized to mast cells, mucosal epithelial cells, non-lymphoid leukocytes, smooth muscle tissue, as well as myenteric and submucosal ganglia where Panx2 is co-localized with $\beta$-tubulin, substance $P$, neuronal nitric oxide synthase, calcitonin gene-related peptide, and vesicular acetylcholine transporter (Diezmos et al., 2015). Cx43 is found throughout the smooth muscle layer, on interstitial cells of Cajal, and on the cell bodies and processes of enteric ganglia (Nemeth et al., 2000; McClain et al., 2014). As mentioned previously, P2X7R is expressed on submucosal and myenteric ganglia (Gulbransen et al., 2012; Kurashima et al., 2012).

The current consensus is that ATP is released from Panx1 channels and possibly Cx43 hemichannels. This ATP functions in an autocrine and/or paracrine manner in conjunction with P2X7R (Figure 1). In the context of inflammation, activation of the Panx1/P2X7R complex can lead to the formation of the NACHT, LRR, and PYD domains-containing protein 3 inflammasome involving caspase- 1 which in turn leads to release of mature IL-1 $\beta$ (Surprenant and North, 2009). The mechanism by which this occurs however is unknown (Surprenant and North, 2009). Panxl was suggested to regulate ATP release which in conjunction with $\mathrm{P} 2 \mathrm{X} 1, \mathrm{P} 2 \mathrm{X} 4$, and $\mathrm{P} 2 \mathrm{X} 7$ mediates $\mathrm{T}$ cell responses such as $\mathrm{Ca}^{2+}$ entry and IL-2 synthesis (Woehrle et al., 2010a,b). In astrocytes, Panx1 expression is required for the release of IL-6, IL-8, and glutamate (Wei et al., 2016). Interestingly, $\mathrm{Cx} 43$ in astrocytes were shown to open in response to IL-1 $\beta$ and TNF- $\alpha$ release from microglia (Retamal et al., 2007). Panx1 may also have an important role in cell migration. Panx1 and P2X7R via different mechanisms are required for GM-CSF promoted macrophage fusion (Lemaire et al., 2011). A more recent study has shown that activation of vascular endothelial cells by TNF- $\alpha$ causes Panx1-mediated ATP release, leading

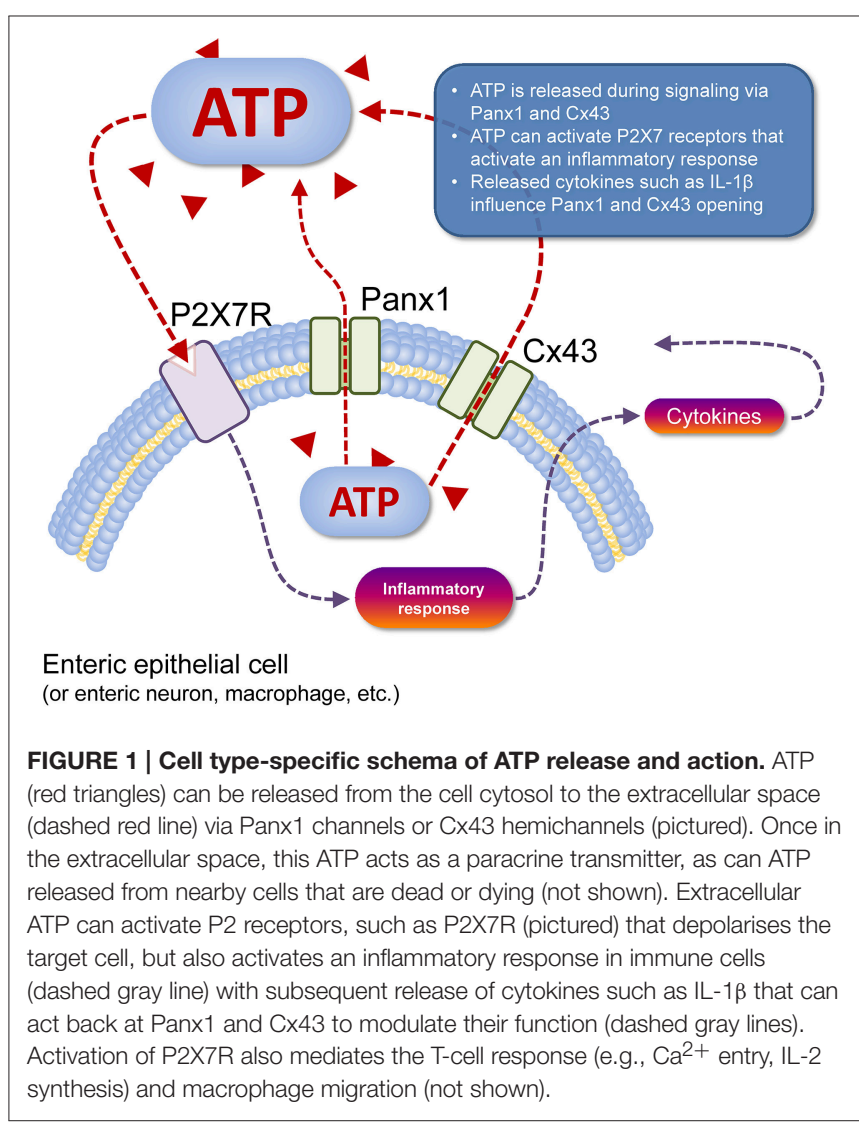


to leukocyte migration during inflammation (Lohman et al., 2015).

UC and CD can be differentiated by the cytokine profile exhibited during disease (Khor et al., 2011). UC is thought to be Th2 cell mediated and is associated with elevated IL5 levels and a lack of IL-2 or IFN- $\gamma$ increase (Fuss et al., 1996; Sanchez-Munoz et al., 2008). CD on the other hand is suggested to be Th1 and Th17 cell mediated with elevated IFN- $\gamma$ and IL-22 (Fuss et al., 1996; Monteleone et al., 1997; Plevy et al., 1997; Sanchez-Munoz et al., 2008; Strober and Fuss, 2011). Common to both UC and CD inflammation are elevated levels of TNF $\alpha$, IL-1 $\beta$, IL-6, IL-8, IL-12, and IL-17 (Fiocchi, 1998; Papadakis and Targan, 2000; Sanchez-Munoz et al., 2008; Strober and Fuss, 2011). Thus, the altered expression of cytokines observed in IBD may be linked to the differential expression of Panx1 and Cx43 that is seen between certain cell types.

Most studies have concluded that Panxl is the more important channel in mediating ATP release and in conjunction with P2X7R is important in cytokine release such as IL- $1 \beta$ (Pelegrin et al., 2008; Iglesias et al., 2009; Lemaire et al., 2011; Thi et al., 2012; Orellana et al., 2013; Baxter et al., 2014; Kanjanamekanant et al., 2014; Ohbuchi et al., 2014; Poon et al., 2014; Shoji et al., 2014). Nonetheless, at least three studies have concluded that $\mathrm{Cx} 43$ as the more important channel in ATP release and inflammation particularly in enteric glia (Decrock et al., 2009; Csoka et al., 2015; Brown et al., 2016). Finally, some studies have concluded that neither Cx43 nor Panx1 have a significant influence on ATP release (Kurashima et al., 2012; Avendaño et al., 2015). In some cases, P2X7R activation is independent of their expression (Alberto et al., 2013; Hansen et al., 2014). Thus, it is still difficult to determine whether Panx1 and/or Cx43 will play a more influential role in the pathophysiology of IBD if one does indeed exist. Table 2 summarizes a range of articles that have determined whether Panx 1 or $\mathrm{Cx} 43$ is more important for ATP release.

\section{PHARMACOLOGICAL TOOLS AND KNOCKOUT MICE}

The pharmacological tools available in the current field of pannexin and connexin research have gradually improved with the availability of more selective channel blockers. However, there is still a lack of high affinity inhibitors for most pannexins and connexins. For connexins, both gap junction and hemichannel activity needs to be considered (Verselis and Srinivas, 2013). Carbenoxolone has been used as a connexin channel blocker but has since been shown to block Panx1 channels and alter network activity of cultured neurons (Rouach et al., 2003). The Cx43 mimetic peptide 5 and peptide Gap19 selectively block Cx43 hemichannels but not gap junctions or other connexin hemichannels (O'Carroll et al., 2008; Wang et al., 2013b). For pannexin channels, only selective Panxl channels blockers exist such as mefloquine, probenecid and ${ }^{10} \mathrm{Panx} 1$ (Good et al., 2015). However, these tools are not selective enough to determine underlying Panx1 channel mechanisms due to additional effects on proteins such as connexins (Good et al., 2015). In contrast, the pharmacological tools for P2 receptors include selective antagonists for many receptors. For example, the specific receptor antagonists A-438079 and A740003 have been developed for P2X7R (Donnelly-Roberts and Jarvis, 2007).

A selection of knockout mice for connexins, pannexins and P2X7R has been generated in previous studies. Pannexins and connexins are generally well-conserved between humans and mice. Pannexins show 93-94\% conservation at the protein level (Penuela et al., 2009). Likewise, Cx43 and Cx45 show 98\% conservation at the genetic level, making mice a translatable animal model (Sohl and Willecke, 2004). Panx1 knockouts have been previously explored in another review article, showing that there were no major phenotypic abnormalities in the knockout mice despite wide-spread expression of Panx1 (Penuela et al., 2013). Pan $\times 2^{-/-}$knockout mice have been generated and did not show major differences in phenotype compared to wild type mice (Bargiotas et al., 2011). However as mentioned above, $\mathrm{Panx}^{-/-}$and Panx2 $2^{-/-}$double knockout mice were shown to have resistance to ischemic stroke (Bargiotas et al., 2011). The development of Panx3 knockout mice has recently been published and mice lacking the Panx 3 gene were shown to be less susceptible to osteoarthritis development (Moon et al., 2015). Connexin knockouts have previously been reviewed in the context of cardiac function, showing that a large number of connexin knockouts are lethal (Lo, 2000). The $\mathrm{Cx} 43^{+/-}$ heterozygous knockout mice are able to survive adulthood but show a ventricular conduction phenotype (Guerrero et al., 1997). As mentioned previously, mice with a conditional knockout of $\mathrm{Cx} 43$ in GI smooth muscle showed decreased motility (Doring et al., 2007). In P2X7R knockout mice macrophages were found to lack the ability to release IL-1 (Solle et al., 2001).

Using combinations of the available pharmacological tools and knockout mice hold promise in the progression of research in this field. The hope is to confirm the specific roles of pannexins and connexins in ATP release and in disease pathophysiology. This task is made difficult by the still weak selection of pharmacological tools available and the potential problems of compensation by other subtypes in gene silencing and knockout models. For instance, Panx3 is not normally expressed on blood vessels but is significantly upregulated in the arterial wall of Panxl knockout mice (Lohman and Isakson, 2014).

\section{CONCLUSIONS AND FUTURE DIRECTIONS}

The role of pannexin and connexin channels in gut inflammation is an emerging and exciting topic of research. Such research will be useful in determining the etiology of IBD, which is yet to be fully understood. Future studies that examine the extent of pannexin and connexin channel activation would provide valuable knowledge in determining the involvement of P2X7R 
TABLE 2 | Literature focusing on cell type-specific function of Cx43, Panx1, and P2X7R.

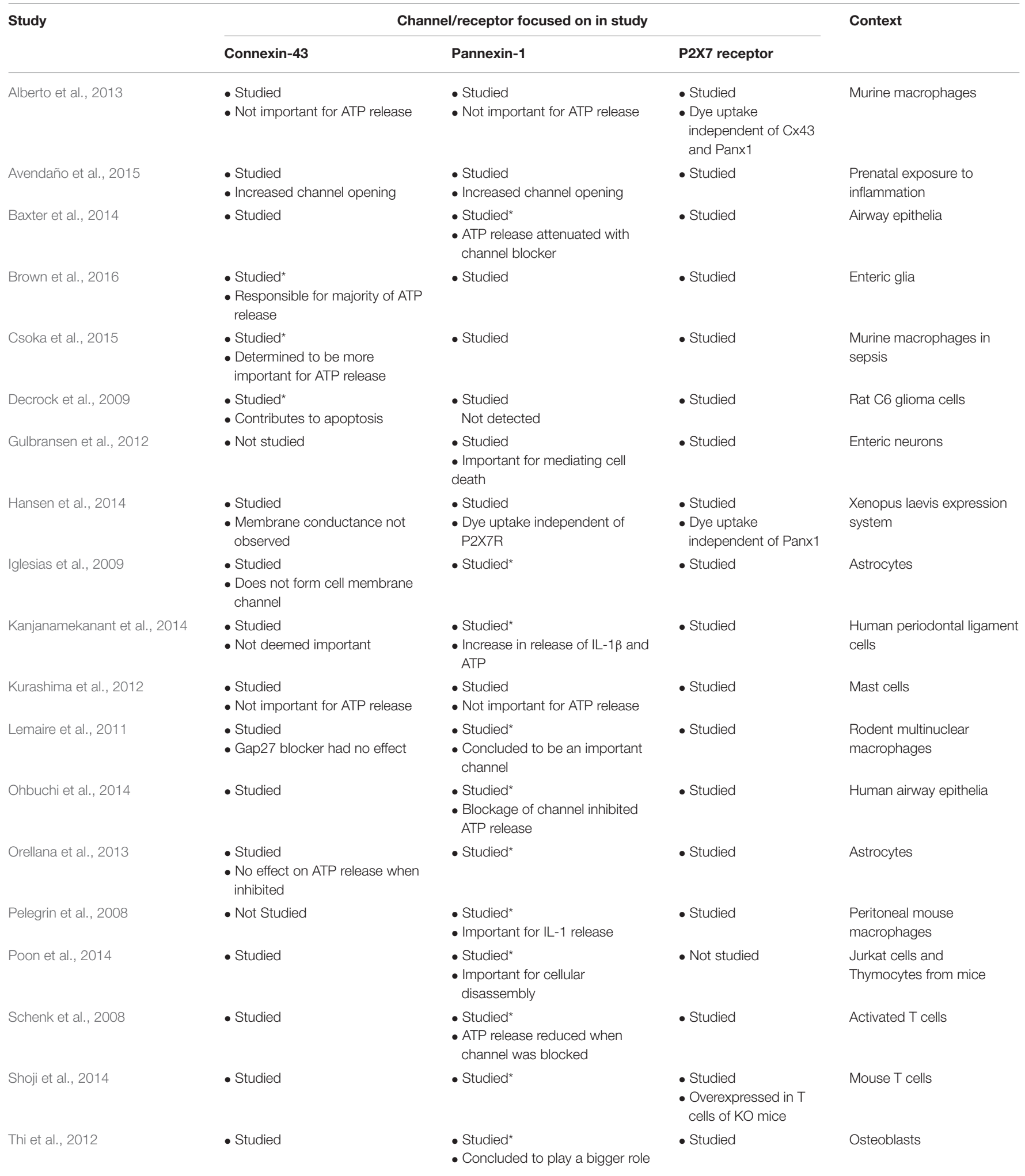

*Specifies the more important or significant channel in the study. 
and other purinergic receptors in the GI system, in both health and disease states, and in defining the potential interactions of Panx1, Cx43 and P2X7R in IBD.

\section{AUTHOR CONTRIBUTIONS}

ED wrote the manuscript and conducted the research, PB conducted the research and assisted with the writing and editing

\section{REFERENCES}

Adinolfi, E., Raffaghello, L., Giuliani, A. L., Cavazzini, L., Capece, M., Chiozzi, P., et al. (2012). Expression of P2X7 receptor increases in vivo tumor growth. Cancer Res. 72, 2957-2969. doi: 10.1158/0008-5472.CAN-11-1947

Alberto, A. V., Faria, R. X., Couto, C. G., Ferreira, L. G., Souza, C. A., Teixeira, P. C., et al. (2013). Is pannexin the pore associated with the P2X7 receptor? Naunyn Schmiedebergs Arch. Pharmacol. 386, 775-787. doi: 10.1007/s00210-013-0 $868-\mathrm{x}$

Antonioli, L., Giron, M. C., Colucci, R., Pellegrini, C., Sacco, D., Caputi, V., et al. (2014). Involvement of the P2X7 purinergic receptor in colonic motor dysfunction associated with bowel inflammation in rats. PLoS ONE 9:e116253. doi: 10.1371/journal.pone.0116253

Antonioli, L., Pacher, P., Vizi, E. S., and Hasko, G. (2013). CD39 and CD73 in immunity and inflammation. Trends Mol. Med. 19, 355-367. doi: 10.1016/j.molmed.2013.03.005

Avendaño, B. C., Montero, T. D., Chávez, C. E., von Bernhardi, R., and Orellana, J. A. (2015). Prenatal exposure to inflammatory conditions increases $\mathrm{Cx} 43$ and Panx1 unopposed channel opening and activation of astrocytes in the offspring effect on neuronal survival. Glia 63, 2058-2072. doi: 10.1002/glia.22877

Bao, L., Locovei, S., and Dahl, G. (2004). Pannexin membrane channels are mechanosensitive conduits for ATP. FEBS Lett. 572, 65-68. doi: 10.1016/j.febs let.2004.07.009

Bao, Y., Chen, Y., Ledderose, C., Li, L., and Junger, W. G. (2013). Pannexin 1 channels link chemoattractant receptor signaling to local excitation and global inhibition responses at the front and back of polarized neutrophils. J. Biol. Chem. 288, 22650-22657. doi: 10.1074/jbc.M113.476283

Baranova, A., Ivanov, D., Petrash, N., Pestova, A., Skoblov, M., Kelmanson, I., et al. (2004). The mammalian pannexin family is homologous to the invertebrate innexin gap junction proteins. Genomics 83, 706-716. doi: 10.1016/j.ygeno.2003.09.025

Bargiotas, P., Krenz, A., Hormuzdi, S. G., Ridder, D. A., Herb, A., Barakat, W., et al. (2011). Pannexins in ischemia-induced neurodegeneration. Proc. Natl. Acad. Sci. U.S.A. 108, 20772-20777. doi: 10.1073/pnas.1018262108

Bargiotas, P., Krenz, A., Monyer, H., and Schwaninger, M. (2012). Functional outcome of pannexin-deficient mice after cerebral ischemia. Channels 6, 453-456. doi: 10.4161/chan.22315

Bartlett, R., Stokes, L., and Sluyter, R. (2014). The P2X7 receptor channel: recent developments and the use of $\mathrm{P} 2 \mathrm{X} 7$ antagonists in models of disease. Pharmacol. Rev. 66, 638-675. doi: 10.1124/pr.113.008003

Baxter, M., Eltom, S., Dekkak, B., Yew-Booth, L., Dubuis, E. D., Maher, S. A., et al. (2014). Role of transient receptor potential and pannexin channels in cigarette smoke-triggered ATP release in the lung. Thorax 69, 1080-1089. doi: 10.1136/thoraxjnl-2014-205467

Beckel, J. M., Argall, A. J., Lim, J. C., Xia, J., Lu, W., Coffey, E. E., et al. (2014). Mechanosensitive release of adenosine 5'-triphosphate through pannexin channels and mechanosensitive upregulation of pannexin channels in optic nerve head astrocytes: a mechanism for purinergic involvement in chronic strain. Glia 62, 1486-1501. doi: 10.1002/glia.22695

Bianco, F., Pravettoni, E., Colombo, A., Schenk, U., Moller, T., Matteoli, M., et al. (2005). Astrocyte-derived ATP induces vesicle shedding and IL-1 beta release from microglia. J. Immunol. 174, 7268-7277. doi: 10.4049/jimmunol.174.11.7268

Boisse, L., Chisholm, S. P., Lukewich, M. K., and Lomax, A. E. (2009). Clinical and experimental evidence of sympathetic neural dysfunction during inflammatory bowel disease. Clin. Exp. Pharmacol. Physiol. 36, 1026-1033. doi: 10.1111/j.1440-1681.2009.05242.x of the manuscript, LL conducted the research and the editing of the manuscript.

\section{ACKNOWLEDGMENTS}

Research in the authors' laboratory was supported by a grant from the National Health and Medical Research Council of Australia (APP1048885).

Bou Saab, J., Losa, D., Chanson, M., and Ruez, R. (2014). Connexins in respiratory and gastrointestinal mucosal immunity. FEBS Lett. 588, 1288-1296. doi: 10.1016/j.febslet.2014.02.059

Brown, I. A., McClain, J. L., Watson, R. E., Patel, B. A., and Gulbransen, B. D. (2016). Enteric glia mediate neuron death in colitis through purinergic pathways that require connexin-43 and nitric oxide. Cell Mol. Gastroenterol. Hepatol. 2, 77-91. doi: 10.1016/j.jcmgh.2015.08.007

Bruzzone, R., Hormuzdi, S. G., Barbe, M. T., Herb, A., and Monyer, H. (2003). Pannexins, a family of gap junction proteins expressed in brain. Proc. Natl. Acad. Sci. U.S.A. 100, 13644-13649. doi: 10.1073/pnas.2233464100

Burnstock, G. (2014). Purinergic signalling in the gastrointestinal tract and related organs in health and disease. Purinergic Signal. 10, 3-50. doi: 10.1007/s11302013-9397-9

Burnstock, G., and Williams, M. (2000). P2 purinergic receptors: modulation of cell function and therapeutic potential. J. Pharmacol. Exp. Ther. 295, 862-869.

Burra, S., and Jiang, J. X. (2009). Connexin 43 hemichannel opening associated with Prostaglandin E(2) release is adaptively regulated by mechanical stimulation. Commun. Integr. Biol. 2, 239-240. doi: 10.4161/cib.2.3.8154

Bynoe, M. S., Waickman, A. T., Mahamed, D. A., Mueller, C., Mills, J. H., and Czopik, A. (2012). CD73 is critical for the resolution of murine colonic inflammation. J. Biomed. Biotechnol. 2012:260983. doi: 10.1155/2012/260983

Castelucci, P., Robbins, H. L., Poole, D. P., and Furness, J. B. (2002). The distribution of purine $\mathrm{P} 2 \mathrm{X}(2)$ receptors in the guinea-pig enteric nervous system. Histochem. Cell Biol. 117, 415-422. doi: 10.1007/s00418-002-0404-4

Cesaro, A., Brest, P., Hofman, V., Hebuterne, X., Wildman, S., Ferrua, B., et al. (2010). Amplification loop of the inflammatory process is induced by P2X7R activation in intestinal epithelial cells in response to neutrophil transepithelial migration. Am. J. Physiol. Gastrointest. Liver Physiol. 299, G32-G42. doi: 10.1152/ajpgi.00282.2009

Chekeni, F. B., Elliott, M. R., Sandilos, J. K., Walk, S. F., Kinchen, J. M., Lazarowski, E. R., et al. (2010). Pannexin 1 channels mediate 'find-me' signal release and membrane permeability during apoptosis. Nature 467, 863-867. doi: 10.1038 /nature09413

Cherian, P. P., Siller-Jackson, A. J., Gu, S., Wang, X., Bonewald, L. F., Sprague, E., et al. (2005). Mechanical strain opens connexin 43 hemichannels in osteocytes: a novel mechanism for the release of prostaglandin. Mol. Biol. Cell 16, 3100-3106. doi: 10.1091/mbc.E04-10-0912

Clair, C., Combettes, L., Pierre, F., Sansonetti, P., and Tran Van Nhieu, G. (2008). Extracellular-loop peptide antibodies reveal a predominant hemichannel organization of connexins in polarized intestinal cells. Exp. Cell Res. 314, 1250-1265. doi: 10.1016/j.yexcr.2007.12.021

Corriden, R., and Insel, P. A. (2010). Basal release of ATP: an autocrine-paracrine mechanism for cell regulation. Sci Signal. 3:re1. doi: 10.1126/scisignal.3104re1

Csoka, B., Nemeth, Z. H., Toro, G., Idzko, M., Zech, A., Koscso, B., et al. (2015). Extracellular ATP protects against sepsis through macrophage $\mathrm{P} 2 \mathrm{X} 7$ purinergic receptors by enhancing intracellular bacterial killing. FASEB J. 29, 3626-3637. doi: 10.1096/fj.15-272450

da Silva, M. V., Marosti, A. R., Mendes, C. E., Palombit, K., and Castelucci, P. (2015). Differential effects of experimental ulcerative colitis on P2X7 receptor expression in enteric neurons. Histochem. Cell Biol. 143, 171-184. doi: 10.1007/s00418-014-1270-6

de Campos, N. E., Marques-da-Silva, C., Correa, G., Castelo-Branco, M. T., de Souza, H. S., and Coutinho-Silva, R. (2012). Characterizing the presence and sensitivity of the $\mathrm{P} 2 \mathrm{X} 7$ receptor in different compartments of the gut. J. Innate Immun. 4, 529-541. doi: 10.1159/000336628

Decrock, E., De Vuyst, E., Vinken, M., Van Moorhem, M., Vranckx, K., Wang, N., et al. (2009). Connexin 43 hemichannels contribute to the propagation of 
apoptotic cell death in a rat C6 glioma cell model. Cell Death Differ. 16, 151-163. doi: $10.1038 /$ cdd.2008.138

De Vuyst, E., Decrock, E., Cabooter, L., Dubyak, G. R., Naus, C. C., Evans, W. H., et al. (2006). Intracellular calcium changes trigger connexin 32 hemichannel opening. EMBO J. 25, 34-44. doi: 10.1038/sj.emboj.76 00908

De Vuyst, E., Wang, N., Decrock, E., De Bock, M., Vinken, M., Van Moorhem, M., et al. (2009). $\mathrm{Ca}(2+)$ regulation of connexin 43 hemichannels in $\mathrm{C} 6$ glioma and glial cells. Cell Calcium 46, 176-187. doi: 10.1016/j.ceca.2009.07.002

D'Hondt, C., Ponsaerts, R., De Smedt, H., Bultynck, G., and Himpens, B. (2009). Pannexins, distant relatives of the connexin family with specific cellular functions? Bioessays 31, 953-974. doi: 10.1002/bies.200800236

Diezmos, E. F., Sandow, S. L., Markus, I., Shevy Perera, D., Lubowski, D. Z., King, D. W., et al. (2013). Expression and localization of pannexin-1 hemichannels in human colon in health and disease. Neurogastroenterol. Motil. 25, e395-e405. doi: $10.1111 / \mathrm{nmo} .12130$

Diezmos, E. F., Sandow, S. L., Perera, D. S., King, D. W., Bertrand, P. P., and Liu, L. (2015). Pannexin-2 is expressed in the human colon with extensive localization in the enteric nervous system. Neurogastroenterol. Motil. 27, 672-683. doi: $10.1111 / \mathrm{nmo} .12541$

Doctor, R. B., Matzakos, T., McWilliams, R., Johnson, S., Feranchak, A. P., and Fitz, J. G. (2005). Purinergic regulation of cholangiocyte secretion: identification of a novel role for P2X receptors. Am. J. Physiol. Gastrointest. Liver Physiol. 288, G779-G786. doi: 10.1152/ajpgi.00325.2004

Donnelly-Roberts, D. L., and Jarvis, M. F. (2007). Discovery of P2X7 receptorselective antagonists offers new insights into P2X7 receptor function and indicates a role in chronic pain states. Br. J. Pharmacol. 151, 571-579. doi: 10.1038/sj.bjp. 0707265

Doring, B., Pfitzer, G., Adam, B., Liebregts, T., Eckardt, D., Holtmann, G., et al. (2007). Ablation of connexin 43 in smooth muscle cells of the mouse intestine: functional insights into physiology and morphology. Cell Tissue Res. 327, 333-342. doi: 10.1007/s00441-006-0281-6

Eltzschig, H. K., Eckle, T., Mager, A., Kuper, N., Karcher, C., Weissmuller, T., et al. (2006). ATP release from activated neutrophils occurs via connexin 43 and modulates adenosine-dependent endothelial cell function. Circ. Res. 99, 1100-1108. doi: 10.1161/01.RES.0000250174.31269.70

Ezumi, K., Yamamoto, H., Murata, K., Higashiyama, M., Damdinsuren, B., Nakamura, Y., et al. (2008). Aberrant expression of connexin 26 is associated with lung metastasis of colorectal cancer. Clin. Cancer Res. 14, 677-684. doi: 10.1158/1078-0432.CCR-07-1184

Fiocchi, C. (1998). Inflammatory bowel disease: etiology and pathogenesis. Gastroenterology 115, 182-205. doi: 10.1016/S0016-5085(98)70381-6

Fortes, F. S., Pecora, I. L., Persechini, P. M., Hurtado, S., Costa, V., Coutinho-Silva, R., et al. (2004). Modulation of intercellular communication in macrophages: possible interactions between GAP junctions and P2 receptors. J. Cell Sci. 117(Pt 20), 4717-4726. doi: 10.1242/jcs.01345

Friedman, D. J., Kunzli, B. M., A-Rahim, Y. I., Sevigny, J., Berberat, P. O., Enjyoji, K., et al. (2009). From the Cover: CD39 deletion exacerbates experimental murine colitis and human polymorphisms increase susceptibility to inflammatory bowel disease. Proc. Natl. Acad. Sci. U.S.A. 106, 16788-16793. doi: $10.1073 /$ pnas. 0902869106

Frinchi, M., Di Liberto, V., Turimella, S., D’Antoni, F., Theis, M., Belluardo, N., et al. (2013). Connexin36 (Cx36) expression and protein detection in the mouse carotid body and myenteric plexus. Acta Histochem. 115, 252-256. doi: 10.1016/j.acthis.2012.07.005

Fuss, I. J., Neurath, M., Boirivant, M., Klein, J. S., de la Motte, C., Strong, S. A., et al. (1996). Disparate CD4+ lamina propria (LP) lymphokine secretion profiles in inflammatory bowel disease. Crohn's disease LP cells manifest increased secretion of IFN-gamma, whereas ulcerative colitis LP cells manifest increased secretion of IL-5. J. Immunol. 157, 1261-1270.

Gallego, D., Hernandez, P., Clave, P., and Jimenez, M. (2006). P2Y1 receptors mediate inhibitory purinergic neuromuscular transmission in the human colon. Am. J. Physiol. Gastrointest. Liver Physiol. 291, G584-G594. doi: 10.1152/ajpgi.00474.2005

Gallego, D., Vanden Berghe, P., Farre, R., Tack, J., and Jimenez, M. (2008). P2Y1 receptors mediate inhibitory neuromuscular transmission and enteric neuronal activation in small intestine. Neurogastroenterol. Motil. 20, 159-168. doi: $10.1111 / j .1365-2982.2007 .01004 . x$
Gibson, D. J., Elliott, L., McDermott, E., Tosetto, M., Keegan, D., Byrne, K., et al (2015). Heightened expression of cd39 by regulatory t lymphocytes is associated with therapeutic remission in inflammatory bowel disease. Inflamm. Bowel Dis. 21, 2806-2814. doi: 10.1097/MIB.0000000000000566

Good, M. E., Begandt, D., DeLalio, L. J., Keller, A. S., Billaud, M., and Isakson, B. E. (2015). Emerging concepts regarding pannexin 1 in the vasculature. Biochem. Soc. Trans. 43, 495-501. doi: 10.1042/BST20150045

Guerrero, P. A., Schuessler, R. B., Davis, L. M., Beyer, E. C., Johnson, C. M., Yamada, K. A., et al. (1997). Slow ventricular conduction in mice heterozygous for a connexin43 null mutation. J. Clin. Invest. 99, 1991-1998. doi: 10.1172/JCI119367

Gulbransen, B. D., Bashashati, M., Hirota, S. A., Gui, X., Roberts, J. A., MacDonald, J. A., et al. (2012). Activation of neuronal P2X7 receptorpannexin-1 mediates death of enteric neurons during colitis. Nat. Med. 18, 600-604. doi: 10.1038/nm.2679

Guttman, J. A., Lin, A. E., Li, Y., Bechberger, J., Naus, C. C., Vogl, A. W., et al. (2010). Gap junction hemichannels contribute to the generation of diarrhoea during infectious enteric disease. Gut 59, 218-226. doi: 10.1136/gut.2008.170464

Guzman, J., Yu, J. G., Suntres, Z., Bozarov, A., Cooke, H., Javed, N., et al. (2006). ADOA3R as a therapeutic target in experimental colitis: proof by validated high-density oligonucleotide microarray analysis. Inflamm. Bowel Dis. 12, 766-789. doi: 10.1097/00054725-200608000-00014

Hansen, D. B., Ye, Z. C., Calloe, K., Braunstein, T. H., Hofgaard, J. P., Ransom, B. R., et al. (2014). Activation, permeability, and inhibition of astrocytic and neuronal large pore (hemi)channels. J. Biol. Chem. 289, 26058-26073. doi: 10.1074/jbc.M114.582155

Hofman, P., Cherfils-Vicini, J., Bazin, M., Ilie, M., Juhel, T., Hebuterne, X., et al. (2015). Genetic and pharmacological inactivation of the purinergic P2RX7 receptor dampens inflammation but increases tumor incidence in a mouse model of colitis-associated cancer. Cancer Res. 75, 835-845. doi: 10.1158/00085472.CAN-14-1778

Idzko, M., Ferrari, D., and Eltzschig, H. K. (2014). Nucleotide signalling during inflammation. Nature 509, 310-317. doi: 10.1038/nature13085

Iglesias, R., Dahl, G., Qiu, F., Spray, D. C., and Scemes, E. (2009). Pannexin 1: the molecular substrate of astrocyte "hemichannels." J. Neurosci. 29, 7092-7097. doi: 10.1523/JNEUROSCI.6062-08.2009

Ishikawa, M., Iwamoto, T., Nakamura, T., Doyle, A., Fukumoto, S., and Yamada, Y. (2011). Pannexin 3 functions as an ER Ca(2+) channel, hemichannel, and gap junction to promote osteoblast differentiation. J. Cell Biol. 193, 1257-1274. doi: $10.1083 /$ jcb. 201101050

Junger, W. G. (2011). Immune cell regulation by autocrine purinergic signalling. Nat. Rev. Immunol. 11, 201-212. doi: 10.1038/nri2938

Kanczuga-Koda, L., Sulkowski, S., Koda, M., Sobaniec-Lotowska, M., and Sulkowska, M. (2004). Expression of connexins 26, 32 and 43 in the human colon-an immunohistochemical study. Folia Histochem. Cytobiol. 42, 203-207.

Kang, J., Kang, N., Lovatt, D., Torres, A., Zhao, Z., Lin, J., et al. (2008). Connexin 43 hemichannels are permeable to ATP. J. Neurosci. 28, 4702-4711. doi: 10.1523/JNEUROSCI.5048-07.2008

Kanjanamekanant, K., Luckprom, P., and Pavasant, P. (2014). P2X7 receptorPannexin 1 interaction mediates stress-induced interleukin-1 beta expression in human periodontal ligament cells. J. Periodont. Res. 49, 595-602. doi: $10.1111 /$ jre.12139

Khor, B., Gardet, A., and Xavier, R. J. (2011). Genetics and pathogenesis of inflammatory bowel disease. Nature 474, 307-317. doi: 10.1038/nature10209

Koutsoumpas, A., Polymeros, D., Tsiamoulos, Z., Smyk, D., Karamanolis, G., Triantafyllou, K., et al. (2011). Peculiar antibody reactivity to human connexin 37 and its microbial mimics in patients with Crohn's disease. J. Crohns. Colitis 5, 101-109. doi: 10.1016/j.crohns.2010.10.009

Kuhny, M., Hochdorfer, T., Ayata, C. K., Idzko, M., and Huber, M. (2014). CD39 is a negative regulator of $\mathrm{P} 2 \mathrm{X} 7$-mediated inflammatory cell death in mast cells. Cell Commun. Signal. 12:40. doi: 10.1186/s12964-014-0040-3

Kurashima, Y., Amiya, T., Nochi, T., Fujisawa, K., Haraguchi, T., Iba, H., et al. (2012). Extracellular ATP mediates mast cell-dependent intestinal inflammation through P2X7 purinoceptors. Nat. Commun. 3, 1034. doi: $10.1038 /$ ncomms 2023

Lai, C., Bechberger, J., and Naus, C. (2009). Pannexin2 as a novel growth regulator in C6 glioma cells. Oncogene 28, 4402-4408. doi: 10.1038/onc.2009.283 
Lemaire, I., Falzoni, S., Zhang, B., Pellegatti, P., and Di Virgilio, F. (2011). The P2X7 receptor and Pannexin-1 are both required for the promotion of multinucleated macrophages by the inflammatory cytokine GM-CSF. J. Immunol. 187, 3878-3887. doi: 10.4049/jimmunol.1002780

Li, S., Bjelobaba, I., Yan, Z., Kucka, M., Tomic, M., and Stojilkovic, S. S. (2011). Expression and roles of pannexins in ATP release in the pituitary gland. Endocrinology 152, 2342-2352. doi: 10.1210/en.2010-1216

Linan-Rico, A., Wunderlich, J. E., Grants, I. S., Frankel, W. L., Xue, J., Williams, K. C., et al. (2013). Purinergic autocrine regulation of mechanosensitivity and serotonin release in a human EC model: ATP-gated P2X3 channels in EC are downregulated in ulcerative colitis. Inflamm. Bowel Dis. 19, 2366-2379. doi: 10.1097/MIB.0b013e31829ecf4d

Lo, C. W. (2000). Role of gap junctions in cardiac conduction and development: insights from the connexin knockout mice. Circ. Res. 87, 346-348. doi: 10.1161/01.RES.87.5.346

Locovei, S., Bao, L., and Dahl, G. (2006a). Pannexin 1 in erythrocytes: function without a gap. Proc. Natl. Acad. Sci. U.S.A. 103, 7655-7659. doi: 10.1073/pnas.0601037103

Locovei, S., Scemes, E., Qiu, F., Spray, D. C., and Dahl, G. (2007). Pannexin1 is part of the pore forming unit of the $\mathrm{P} 2 \mathrm{X}(7)$ receptor death complex. FEBS Lett. 581, 483-488. doi: 10.1016/j.febslet.2006.12.056

Locovei, S., Wang, J., and Dahl, G. (2006b). Activation of pannexin 1 channels by ATP through P2Y receptors and by cytoplasmic calcium. FEBS Lett. 580, 239-244. doi: 10.1016/j.febslet.2005.12.004

Lohman, A. W., and Isakson, B. E. (2014). Differentiating connexin hemichannels and pannexin channels in cellular ATP release. FEBS Lett. 588, 1379-1388. doi: 10.1016/j.febslet.2014.02.004

Lohman, A. W., Leskov, I. L., Butcher, J. T., Johnstone, S. R., Stokes, T. A., Begandt, D., et al. (2015). Pannexin 1 channels regulate leukocyte emigration through the venous endothelium during acute inflammation. Nat. Commun. 6, 7965. doi: 10.1038/ncomms8965

Lomax, A. E., O'Reilly, M., Neshat, S., and Vanner, S. J. (2007). Sympathetic vasoconstrictor regulation of mouse colonic submucosal arterioles is altered in experimental colitis. J. Physiol. 583(Pt 2), 719-730. doi: 10.1113/jphysiol.2007.136838

Longhi, M. S., Moss, A., Bai, A., Wu, Y., Huang, H., Cheifetz, A., et al. (2014). Characterization of human CD39+ Th17 cells with suppressor activity and modulation in inflammatory bowel disease. PLoS ONE 9:e87956. doi: 10.1371/journal.pone.0087956

Lurtz, M. M., and Louis, C. F. (2007). Intracellular calcium regulation of connexin43. Am. J. Physiol. Cell Physiol. 293, C1806-C1813. doi: 10.1152/ajpcell.00630.2006

Lutz, S. E., Gonzalez-Fernandez, E., Ventura, J. C., Perez-Samartin, A., Tarassishin, L., Negoro, H., et al. (2013). Contribution of pannexin1 to experimental autoimmune encephalomyelitis. PLOS ONE. 8:e66657. doi: 10.1371/journal.pone.0066657

Ma, Y., Cao, W., Wang, L., Jiang, J., Nie, H., Wang, B., et al. (2014). Basal CD38/cyclic ADP-ribose-dependent signaling mediates ATP release and survival of microglia by modulating connexin 43 hemichannels. Glia 62, 943-955. doi: 10.1002/glia.22651

Mahi, N., Kumar, A., Jaggi, A. S., Singh, N., and Dhawan, R. (2015). Possible role of pannexin 1/P2x7 purinoceptor in neuroprotective mechanism of ischemic postconditioning in mice. J. Surg. Res. 196, 190-199. doi: 10.1016/j.jss.2015.02.050

Marques, C. C., Castelo-Branco, M. T., Pacheco, R. G., Buongusto, F., do Rosario, A. Jr., Schanaider, A., et al. (2014). Prophylactic systemic P2X7 receptor blockade prevents experimental colitis. Biochim. Biophys. Acta. 1842, 65-78. doi: 10.1016/j.bbadis.2013.10.012

Martin, C. A., el-Sabban, M. E., Zhao, L., Burakoff, R., and Homaidan, F. R. (1998). Adhesion and cytosolic dye transfer between macrophages and intestinal epithelial cells. Cell Adhes. Commun. 5, 83-95. doi: 10.3109/15419069809040283

McClain, J. L., Grubisic, V., Fried, D., Gomez-Suarez, R. A., Leinninger, G. M., Sevigny, J., et al. (2014). Ca2+ responses in enteric glia are mediated by connexin- 43 hemichannels and modulate colonic transit in mice. Gastroenterology 146, 497-507. e1. doi: 10.1053/j.gastro.2013.10.061

Monro, R. L., Bertrand, P. P., and Bornstein, J. C. (2004). ATP participates in three excitatory postsynaptic potentials in the submucous plexus of the guinea pig ileum. J. Physiol. 556(Pt 2), 571-584. doi: 10.1113/jphysiol.2004.0 60848

Monteleone, G., Biancone, L., Marasco, R., Morrone, G., Marasco, O., Luzza, F., et al. (1997). Interleukin 12 is expressed and actively released by Crohn's disease intestinal lamina propria mononuclear cells. Gastroenterology 112, 1169-1178. doi: 10.1016/S0016-5085(97)70128-8

Moon, P. M., Penuela, S., Barr, K., Khan, S., Pin, C. L., Welch, I., et al. (2015). Deletion of Panx3 prevents the development of surgically induced osteoarthritis. J Mol. Med. (Berl). 93, 845-856. doi: 10.1007/s00109-015-1311-1

Morita, H., Katsuno, T., Hoshimoto, A., Hirano, N., Saito, Y., and Suzuki, Y. (2004). Connexin 26-mediated gap junctional intercellular communication suppresses paracellular permeability of human intestinal epithelial cell monolayers. Exp. Cell Res. 298, 1-8. doi: 10.1016/j.yexcr.2004.03.046

Nemeth, L., Maddur, S., and Puri, P. (2000). Immunolocalization of the gap junction protein Connexin43 in the interstitial cells of Cajal in the normal and Hirschsprung's disease bowel. J. Pediatr. Surg. 35, 823-828. doi: 10.1053/jpsu.2000.6851

Neves, A. R., Castelo-Branco, M. T., Figliuolo, V. R., Bernardazzi, C., Buongusto, F., Yoshimoto, A., et al. (2014). Overexpression of ATPactivated P2X7 receptors in the intestinal mucosa is implicated in the pathogenesis of Crohn's disease. Inflamm. Bowel Dis. 20, 444-457. doi: 10.1097/01.MIB.0000441201.10454.06

Nicotra, L. L., Vu, M., Harvey, B. S., and Smid, S. D. (2013). Prostaglandin ethanolamides attenuate damage in a human explant colitis model. Prostaglandins Other Lipid Mediat. 100-101, 22-29. doi: 10.1016/j.prostaglandins.2013.01.003

North, R. A. (2002). Molecular physiology of P2X receptors. Physiol. Rev. 82, 1013-1067. doi: 10.1152/physrev.00015.2002

O'Carroll, S. J., Alkadhi, M., Nicholson, L. F., and Green, C. R. (2008). Connexin 43 mimetic peptides reduce swelling, astrogliosis, and neuronal cell death after spinal cord injury. Cell Commun. Adhes. 15, 27-42. doi: $10.1080 / 15419060802014164$

Ochoa-Cortes, F., Linan-Rico, A., Jacobson, K. A., and Christofi, F. L. (2014), Potential for developing purinergic drugs for gastrointestinal diseases. Inflamm. Bowel Dis. 20, 1259-1287. doi: 10.1097/MIB.0000000000000047

Ohbuchi, T., Takenaga, F., Hohchi, N., Wakasugi, T., Ueta, Y., and Suzuki, H. (2014). Possible contribution of pannexin-1 to ATP release in human upper airway epithelia. Physiol. Rep. 2:e00227. doi: 10.1002/phy2.227

Orellana, J. A., Montero, T. D., and von Bernhardi, R. (2013). Astrocytes inhibit nitric oxide-dependent $\mathrm{Ca}(2+)$ dynamics in activated microglia: involvement of ATP released via pannexin 1 channels. Glia 61, 2023-2037. doi: 10.1002/glia.22573

Papadakis, K. A., and Targan, S. R. (2000). Role of cytokines in the pathogenesis of inflammatory bowel disease. Annu. Rev. Med. 51, 289-298. doi: 10.1146/annurev.med.51.1.289

Patel, B. A. (2014). Mucosal adenosine triphosphate mediates serotonin release from ileal but not colonic guinea pig enterochromaffin cells. Neurogastroenterol. Motil. 26, 237-246. doi: 10.1111/nmo.12254

Pelegrin, P., Barroso-Gutierrez, C., and Surprenant, A. (2008). P2X7 receptor differentially couples to distinct release pathways for IL-1beta in mouse macrophage. J. Immunol. 180, 7147-7157. doi: 10.4049/jimmunol.180.11.7147

Pelegrin, P., and Surprenant, A. (2006). Pannexin-1 mediates large pore formation and interleukin-1beta release by the ATP-gated P2X7 receptor. EMBO J. 25, 5071-5082. doi: 10.1038/sj.emboj.7601378

Pelegrin, P., and Surprenant, A. (2009). The P2X(7) receptor-pannexin connection to dye uptake and IL-1beta release. Purinergic Signal. 5, 129-137. doi: 10.1007/s11302-009-9141-7

Penuela, S., Bhalla, R., Nag, K., and Laird, D. W. (2009). Glycosylation regulates pannexin intermixing and cellular localization. Mol. Biol. Cell 20, 4313-4323. doi: 10.1091/mbc.E09-01-0067

Penuela, S., Gehi, R., and Laird, D. W. (2013). The biochemistry and function of pannexin channels. Biochim. Biophys. Acta 1828, 15-22. doi: 10.1016/j.bbamem.2012.01.017

Plevy, S. E., Landers, C. J., Prehn, J., Carramanzana, N. M., Deem, R. L., Shealy, D., et al. (1997). A role for TNF-alpha and mucosal T helper-1 cytokines in the pathogenesis of Crohn's disease. J. Immunol. 159, 6276-6282.

Poole, D. P., Castelucci, P., Robbins, H. L., Chiocchetti, R., and Furness, J. B. (2002). The distribution of P2X3 purine receptor subunits in the guinea pig 
enteric nervous system. Auton. Neurosci. 101, 39-47. doi: 10.1016/S15660702(02)00179-0

Poon, I. K., Chiu, Y. H., Armstrong, A. J., Kinchen, J. M., Juncadella, I. J., Bayliss, D. A., et al. (2014). Unexpected link between an antibiotic, pannexin channels and apoptosis. Nature 507, 329-334. doi: 10.1038/nature13147

Qiu, F., and Dahl, G. (2009). A permeant regulating its permeation pore: inhibition of pannexin 1 channels by ATP. Am. J. Physiol. Cell Physiol. 296, C250-C255. doi: 10.1152/ajpcell.00433.2008

Ralevic, V., and Burnstock, G. (1998). Receptors for purines and pyrimidines. Pharmacol. Rev. 50, 413-492.

Ransford, G. A., Fregien, N., Qiu, F., Dahl, G., Conner, G. E., and Salathe, M. (2009). Pannexin 1 contributes to ATP release in airway epithelia. Am. J. Respir. Cell Mol. Biol. 41, 525-534. doi: 10.1165/rcmb.2008-0367OC

Ren, J., and Bertrand, P. P. (2008). Purinergic receptors and synaptic transmission in enteric neurons. Purinergic Signal. 4, 255-266. doi: 10.1007/s11302-0079088-5

Retamal, M. A., Froger, N., Palacios-Prado, N., Ezan, P., Saez, P. J., Saez, J. C., et al. (2007). Cx43 hemichannels and gap junction channels in astrocytes are regulated oppositely by proinflammatory cytokines released from activated microglia. J. Neurosci. 27, 13781-13792. doi: 10.1523/JNEUROSCI.204207.2007

Rigato, C., Swinnen, N., Buckinx, R., Couillin, I., Mangin, J. M., Rigo, J. M., et al. (2012). Microglia proliferation is controlled by P2X7 receptors in a Pannexin-1independent manner during early embryonic spinal cord invasion. J. Neurosci. 32, 11559-11573. doi: 10.1523/JNEUROSCI.1042-12.2012

Riteau, N., Gasse, P., Fauconnier, L., Gombault, A., Couegnat, M., Fick, L., et al. (2010). Extracellular ATP is a danger signal activating P2X7 receptor in lung inflammation and fibrosis. Am. J. Respir. Crit. Care Med. 182, 774-783. doi: 10.1164/rccm.201003-0359OC

Roberts, J. A., Lukewich, M. K., Sharkey, K. A., Furness, J. B., Mawe, G. M., and Lomax, A. E. (2012). The roles of purinergic signaling during gastrointestinal inflammation. Curr. Opin. Pharmacol. 12, 659-666. doi: 10.1016/j.coph.2012.09.011

Rouach, N., Segal, M., Koulakoff, A., Giaume, C., and Avignone, E. (2003). Carbenoxolone blockade of neuronal network activity in culture is not mediated by an action on gap junctions. J. Physiol. 553(Pt 3), 729-745. doi: 10.1113/jphysiol.2003.053439

Ruan, H. Z., and Burnstock, G. (2005). The distribution of P2X5 purinergic receptors in the enteric nervous system of mouse. Cell Tissue Res. 319, 191-200. doi: 10.1007/s00441-004-1002-7

Rybaczyk, L., Rozmiarek, A., Circle, K., Grants, I., Needleman, B., Wunderlich, J. E., et al. (2009). New bioinformatics approach to analyze gene expressions and signaling pathways reveals unique purine gene dysregulation profiles that distinguish between CD and UC. Inflamm. Bowel Dis. 15, 971-984. doi: $10.1002 /$ ibd.20893

Sanchez-Munoz, F., Dominguez-Lopez, A., and Yamamoto-Furusho, J. K. (2008). Role of cytokines in inflammatory bowel disease. World J. Gastroenterol. 14, 4280-4288. doi: 10.3748/wjg.14.4280

Schenk, U., Westendorf, A. M., Radaelli, E., Casati, A., Ferro, M., Fumagalli, M., et al. (2008). Purinergic control of T cell activation by ATP released through pannexin-1 hemichannels. Sci. Signal. 1:ra6. doi: 10.1126/scisignal.1160583

Schock, S. C., Leblanc, D., Hakim, A. M., and Thompson, C. S. (2008). ATP release by way of connexin 36 hemichannels mediates ischemic tolerance in vitro. Biochem. Biophys. Res. Commun. 368, 138-144. doi: 10.1016/j.bbrc.2008.01.054

Shoji, K. F., Saez, P. J., Harcha, P. A., Aguila, H. L., and Saez, J. C. (2014). Pannexin1 channels act downstream of P2X 7 receptors in ATP-induced murine T-cell death. Channels 8, 142-156. doi: 10.4161/chan.28122

Sohl, G., and Willecke, K. (2004). Gap junctions and the connexin protein family. Cardiovasc. Res. 62, 228-232. doi: 10.1016/j.cardiores.2003.11.013

Solle, M., Labasi, J., Perregaux, D. G., Stam, E., Petrushova, N., Koller, B. H., et al. (2001). Altered cytokine production in mice lacking P2X(7) receptors. J. Biol. Chem. 276, 125-132. doi: 10.1074/jbc.M006781200

Strober, W., and Fuss, I. J. (2011). Proinflammatory cytokines in the pathogenesis of inflammatory bowel diseases. Gastroenterology 140, 1756-1767. doi: 10.1053/j.gastro.2011.02.016

Surprenant, A., and North, R. A. (2009). Signaling at purinergic P2X receptors. Annu. Rev. Physiol. 71, 333-359. doi: 10.1146/annurev.physiol.70 .113006 .100630
Swayne, L. A., Sorbara, C. D., and Bennett, S. A. (2010). Pannexin 2 is expressed by postnatal hippocampal neural progenitors and modulates neuronal commitment. J. Biol. Chem. 285, 24977-24986. doi: 10.1074/jbc.M110.130054

Tanaka, J., Murate, M., Wang, C. Z., Seino, S., and Iwanaga, T. (1996). Cellular distribution of the P2X4 ATP receptor mRNA in the brain and non-neuronal organs of rats. Arch. Histol. Cytol. 59, 485-490. doi: 10.1679/aohc.59.485

Tenneti, L., Gibbons, S. J., and Talamo, B. R. (1998). Expression and trans-synaptic regulation of $\mathrm{P} 2 \mathrm{x} 4$ and $\mathrm{P} 2 \mathrm{z}$ receptors for extracellular ATP in parotid acinar cells. Effects of parasympathetic denervation. J. Biol. Chem. 273, 26799-26808. doi: 10.1074/jbc.273.41.26799

Thi, M. M., Islam, S., Suadicani, S. O., and Spray, D. C. (2012). Connexin43 and pannexin1 channels in osteoblasts: who is the "hemichannel"? J. Membr. Biol. 245, 401-409. doi: 10.1007/s00232-012-9462-2

Vanderwinden, J. M., Timmermans, J. P., and Schiffmann, S. N. (2003). Glial cells, but not interstitial cells, express P2X7, an ionotropic purinergic receptor, in rat gastrointestinal musculature. Cell Tissue Res. 312, 149-154. doi: 10.1007/s00441-003-0716-2

Velasquez Almonacid, L. A., Tafuri, S., Dipineto, L., Matteoli, G., Fiorillo, E., Della Morte, R., et al. (2009). Role of connexin-43 hemichannels in the pathogenesis of Yersinia enterocolitica. Vet. J. 182, 452-457. doi: 10.1016/j.tvjl.2008.08.011

Verselis, V. K., and Srinivas, M. (2013). Connexin channel modulators and their mechanisms of action. Neuropharmacology 75, 517-524. doi: 10.1016/j.neuropharm.2013.03.020

Vinken, M., Vanhaecke, T., and Rogiers, V. (2010). Emerging roles of connexin hemichannels in gastrointestinal and liver pathophysiology. World J. Gastrointest. Pathophysiol. 1, 115-117. doi: 10.4291/wjgp.v1.i4.115

von Kugelgen, I., and Harden, T. K. (2011). Molecular pharmacology, physiology, and structure of the P2Y receptors. Adv. Pharmacol. 61, 373-415. doi: 10.1016/B978-0-12-385526-8.00012-6

Wang, N., De Bock, M., Decrock, E., Bol, M., Gadicherla, A., Vinken, M., et al. (2013a). Paracrine signaling through plasma membrane hemichannels. Biochim. Biophys. Acta 1828, 35-50. doi: 10.1016/j.bbamem.2012.07.002

Wang, N., De Vuyst, E., Ponsaerts, R., Boengler, K., Palacios-Prado, N., Wauman, J., et al. (2013b). Selective inhibition of Cx43 hemichannels by Gap19 and its impact on myocardial ischemia/reperfusion injury. Basic Res. Cardiol. 108:309. doi: $10.1007 /$ s00395-012-0309-x

Wang, Y. F., and Daniel, E. E. (2001). Gap junctions in gastrointestinal muscle contain multiple connexins. Am. J. Physiol. Gastrointest. Liver Physiol. 281, G533-G543.

Wei, L., Sheng, H., Chen, L., Hao, B., Shi, X., and Chen, Y. (2016). Effect of pannexin-1 on the release of glutamate and cytokines in astrocytes. J. Clin. Neurosci. 23, 135-141. doi: 10.1016/j.jocn.2015.05.043

Woehrle, T., Yip, L., Elkhal, A., Sumi, Y., Chen, Y., Yao, Y., et al. (2010a). Pannexin1 hemichannel-mediated ATP release together with P2X1 and P2X4 receptors regulate T-cell activation at the immune synapse. Blood 116, 3475-3484. doi: 10.1182/blood-2010-04-277707

Woehrle, T., Yip, L., Manohar, M., Sumi, Y., Yao, Y., Chen, Y., et al. (2010b). Hypertonic stress regulates $\mathrm{T}$ cell function via pannexin-1 hemichannels and P2X receptors. J. Leukoc. Biol. 88, 1181-1189. doi: 10.1189/jlb.0410211

Xia, J., Lim, J. C., Lu, W., Beckel, J. M., Macarak, E. J., Laties, A. M., et al. (2012). Neurons respond directly to mechanical deformation with pannexin-mediated ATP release and autostimulation of P2X7 receptors. J. Physiol. 590(Pt 10), 2285-2304. doi: 10.1113/jphysiol.2012.227983

Yiangou, Y., Facer, P., Baecker, P. A., Ford, A. P., Knowles, C. H., Chan, C. L., et al (2001). ATP-gated ion channel P2X(3) is increased in human inflammatory bowel disease. Neurogastroenterol. Motil. 13, 365-369. doi: 10.1046/j.13652982.2001.00276.x

Conflict of Interest Statement: The authors declare that the research was conducted in the absence of any commercial or financial relationships that could be construed as a potential conflict of interest.

Copyright (c) 2016 Diezmos, Bertrand and Liu. This is an open-access article distributed under the terms of the Creative Commons Attribution License (CC BY). The use, distribution or reproduction in other forums is permitted, provided the original author(s) or licensor are credited and that the original publication in this journal is cited, in accordance with accepted academic practice. No use, distribution or reproduction is permitted which does not comply with these terms. 